\title{
The Regional Pecularities of Water Use in the Republic of Moldova
}

\author{
Petru Bacal $^{1 \otimes}{ }^{\otimes}$, Daniela Burduja ${ }^{1}$ \\ ${ }^{1}$ Institute of Ecology and Geography, Academy of Economic Science of Moldova
}

\begin{abstract}
The purpose of this research consists in the elucidation of regional and branch aspects of the water use in the Republic of Moldova. The main topics presented in this paper are: 1) the regional delimitations of the Republic of Moldova; 2) resources of surface water and groundwater: 3) regional aspects of water use; 4) dynamics of water use by abstracted sources and by the main usage categories; 5) branch profile of water use and its dynamics: 6) existing problems in the evaluation and monitoring of water use.
\end{abstract}

Keywords: water use, region, technological, agriculture, household.

\section{Introduction}

According to the economic-geographic criterion, the Republic of Moldova (RM) is divided into 4 distinct regions: Northern, Central, Southern and Eastern (figure 1). The North Region (NR) overlaps with the North Development Region, established by the RM Law on Regional Development (Legea nr. 438/2006) and comprises 11 districts from the northern part of the Republic of Moldova, as well as the Balti municipality. The total area of North Region is 10 thousand $\mathrm{km}^{2}$, which represents more than $30 \%$ of the total area of the Republic (table 1). The population of this region is 987 thousand inhabitants $(25 \%)$, including 150 thousand inhabitants - in the Balti city. The largest part of NR is located within the Raut river (the main right tributary of the Dniester River) basin, including the districts of Donduseni, Soroca, Drochia, Floresti, Singerei, as well as Balti municipality. The western part of the region is located in the Prut river basin, including the absolute majority of territory of

\section{CORRESPONDENCE:}

œ pbacal16@gmail.com (P. B.), dana.virlan@mail.ru (D. B.). 
the Briceni, Edinet, Riscani, Glodeni, Falesti districts and about $1 / 2$ of Ocniţa district (Bacal and Burduja, 2017).

The Central Region (CR) includes 13 districts from the central part of the Republic of Moldova, which form the Central Development Region (CDR), as well as the Chisinau municipality, which forms the homonym development region. In addition, at the CDR are attributed the localities from Dubasari district, which are located on the left bank of the Dniester river and are subordinated to the official authorities from Chisinau, including the localities Cocieri, Coşniţa, Pîrîta, Dorotcaia and Corjova. The total area of the Central Region is 11.2 thousand $\mathrm{km}^{2}$ or $33 \%$ of the total area of the Republic. The area of the Central Development Region is 10.6 thousand $\mathrm{km}^{2}(31 \%)$, and of Chisinau municipality is $568 \mathrm{~km}^{2}(1.7 \%)$. The population of the Central Region is $\approx 1.9$ million inhabitants or $\approx 1 / 2$ of the total population of the Republic of Moldova. In the central districts there are 1.1 million people $(26 \%)$, and in Chisinau 814 thousand (20\%). The districts from the central and eastern part of the region are within the boundaries of the Dniester river basin and its tributaries, including in the Raut river basin - the Teleneşti and Orhei districts, the Bâc river - the Călăraşi, Străşeni districts and Chisinau city, the Botna river - Ialoveni district. Most territory of the Ungheni, Nisporeni and Hincesti districts from the western part of the region are located in the Prut river basin. In addition, the eastern part of the Hânceşti district is situated predominantly within the limits of the Cogâlnic river basin, which flows into the Black Sea basins from the current territory of Ukraine.

The Southern Region of the Republic of Moldova occupies a total area of 9.2 thousand $\mathrm{km}^{2}(27 \%)$, including the South Development Region (RDS) - 7.4 thousand $\mathrm{km}^{2}(22 \%)$ and the Gagauzia Development Region - 1.8 thousand $\mathrm{km}^{2}(5.5 \%)$. The population of the South Region is $\approx 700$ thousand inhabitants or $17 \%$ of the total population of the Republic of Moldova, including population of RDS districts - 532 thousand (13\%) and of ATU Gagauzia - 162 thousand (4.0\%). Unlike the North and Central Region, the majority of the territory of the Southern Region is located outside of the Dniester and Prut rivers basins, including in the Ialpug river basin - ATU Gagauzia, Cantemir and Cahul districts, in the Cogâlnic river basin - Cimislia and Basarabeasca districts, in the Sarata and Hadjider rivers basins - Ştefan-Vodă district (Bejan et al., 2017). In the Dniester river basin are located a part of the settlements form the Ştefan-Vodă district, located in the meadow of this river The majority of localities from the Causeni district are located in the Botna river basin - the Dniester tributary. Most of the localities in the Leova and Cantemir districts are located in the Prut river basin, as well as the settlements in the Cahul district located in the meadow of this river.

The Territorial Autonomous Unit from Left Bank of Dniester (TAU LBD) occupies the Râbnita, Dubasari, Grigoriopol and Slobozia districts, as well as the 
Tiraspol municipality. Also, the unrecognized authorities of the separatist region control the territories from the right bank of the Dniester rivert, including the municipality of Thighina (Bender) and 6 communes in its proximity (Gîsca, Proteagailovca, Mereneşti, Zahorna, Chițcani and Cremenciug). Therefore, the de facto area of TAU LBD is 4.2 thousand $\mathrm{km}^{2}$ and the population is 475 thousand inhabitants. Thus, the share of TAU LBD in the area and population of RM is only $12 \%$. At the same time, the share of this region in the total volume of water used is $85 \%$.

\section{Result and discussions}

\subsection{Water resources}

The hydrographic network of the Republic of Moldova is represented by over 3600 water courses, of which only 9 of them have a length of more than $100 \mathrm{~km}$. There are also 4353 natural lakes and artificial pools with a surface area of 42 thousand ha, with a volume of about 1.3 billion. $\mathrm{m}^{3}$, mainly arranged in the river valleys (Cazac et al., 2010). The largest natural lakes along the Dniester river are Bâc $\left(3.7 \mathrm{~km}^{2}\right)$, Roșu $(1.6$ $\left.\mathrm{km}^{2}\right)$, Nistrul Vechi/Old Dniester $\left(1.9 \mathrm{~km}^{2}\right)$. The largest artificial lakes are Dubasari on the Dniester river $\left(67 \mathrm{~km}^{2}\right)$ and Ghidighici on the Bâc river $\left(6.8 \mathrm{~km}^{2}\right)$. Also, within the limits of the Prut river basin, there are 46 accumulated lakes. Costeşti-Stanca is the largest reservoir on the Prut river with an area of $59 \mathrm{~km}^{2}$ and a volume of water of 1.4 billion $\mathrm{m}^{3}$. Also, Lake Costesti-Stânca is also the most important hydropower node on the Prut River.

The total volume of underground water reserves is 1.1 billion $\mathrm{m}^{3} /$ day, inclusive 804 thousand $\mathrm{m}^{3} /$ day $(76 \%)$ of the Dniester river basin, 141 thousand $\mathrm{m}^{3} /$ day $(13 \%)-$ of Prut river basin and 117 thousand $\mathrm{m}^{3} /$ day $(11 \%)$ - of Danube-Black Sea Hydrographical Space. The underground water reserves unevenly distributed across territorial-administrative units. The largest underground water reserves are located in the districts of Anenii-Noi, Criuleni and Orhei from the Central Region, in the Balti municipality from the Northern Region and in the Stefan-Voda district from the Southern Region. Poorly assured with drinking water resources the districts from the Prut river basin, including Râşcani, Glodeni and Falesti from Northern Region, Ungheni, Nisporeni from Central Region, Leova and Cahul from Southern Region. Underground waters are extracted through over 5530 artesian wells.

The mineral underground water resources (drinking and curative) are represented by about 170 fields, of which only 25 are operated, and the other 13 are in the research stage ${ }^{1}$. These waters are insufficiently exploited, except for the deposits

1 2010. Ghidul Nr. 18. Îndrumări cu privire statutul și tendința de evaluare a apelor subterane. Raport tehnic 2010 - 042 
from Cahul, Hârjauca, Camenca, used in the respective spa resorts and Gura Cainarului, Varniţa, Chişinău, Soroca, Balti, whose water is marketed. Also, despite sufficient reserves of surface water, most of the Republic's localities, including from the TAU LBD, are supplied with water from underground sources (figure 1). The degree of water resource assurance is influenced by the geographical position, the amount and the annual course of atmospheric precipitation, by the degree of mineralization and the chemical composition of the groundwater, by the degree of pollution, by the scale and the efficiency of water use.

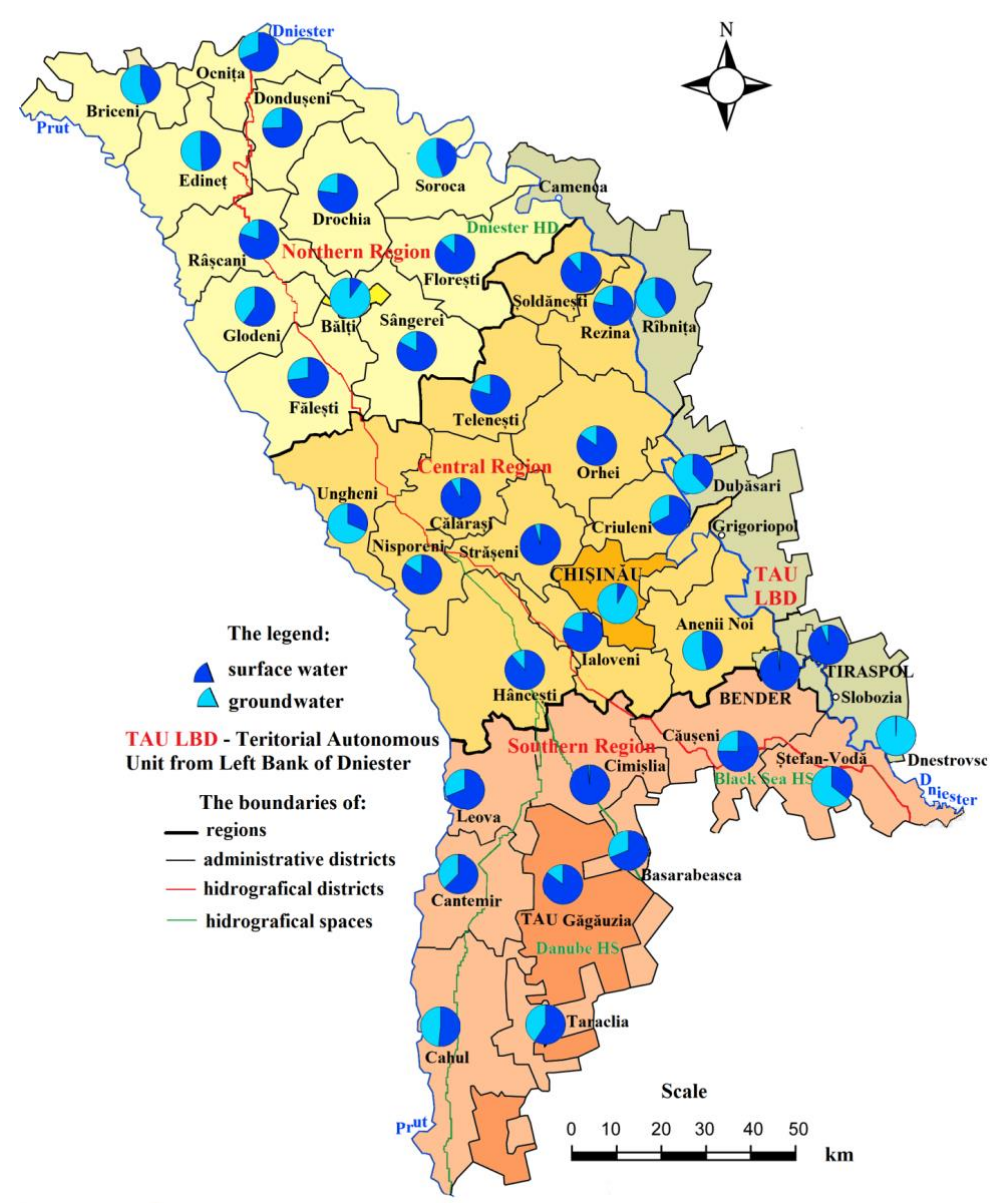

Figure 1. The share of surface and underground waters in the Republic of Moldova

\subsection{The regional analysis of water use}

In the analysed period (2007-2016), the total volume of water used was, on average, 786 million $\mathrm{m}^{3}$, of which 676 million $\mathrm{m}^{3}$ or $86 \%$ is captured from surface sources (table 1). 
Table 1. The regional and local peculiarities of water use in the Republic of Moldova

\begin{tabular}{|c|c|c|c|c|c|c|c|c|c|c|c|c|c|}
\hline \multirow[t]{2}{*}{ Regions and localities } & \multicolumn{3}{|c|}{ Surface } & \multicolumn{3}{|c|}{ Population } & \multicolumn{3}{|c|}{ Total volume of water use } & \multicolumn{2}{|c|}{$\begin{array}{l}\text { Surface } \\
\text { sources }\end{array}$} & \multicolumn{2}{|c|}{$\begin{array}{l}\text { Underground } \\
\text { sources }\end{array}$} \\
\hline & ths $\mathrm{km}^{2}$ & $\%$ & $\%$ & $\begin{array}{c}\text { ths } \\
\text { inhabit. }\end{array}$ & $\%$ & $\%$ & mil. $\mathrm{m}^{3}$ & $\%$ & $\%$ & mil. $\mathrm{m}^{3}$ & $\%$ & mil. $\mathrm{m}^{3}$ & $\%$ \\
\hline North & 10 & 30 & $34^{2}$ & 987 & 25 & 28 & 24.7 & 3.1 & 21 & 11 & 46 & 13.4 & 54 \\
\hline Bălți municipality & 0.08 & 0.2 & 0.3 & 150 & 3.7 & 4.2 & 5.0 & 0.6 & 4.3 & 4.5 & 90 & 0.5 & 10 \\
\hline Central & 11.2 & 33 & 38 & 1874 & 47 & 53 & 76 & 10 & 65 & 55.3 & 73 & 20.2 & 27 \\
\hline Central districts & 10.6 & 31 & 36 & 1060 & 26 & 30 & 24 & 3.1 & 21 & 7.7 & 32 & 16.2 & 68 \\
\hline Chișinău munic. & 0.57 & 1.7 & 1.9 & 814 & 20 & 23 & 52 & 6.6 & 44 & 47.6 & 92 & 4.0 & 8 \\
\hline South & 9.2 & 27 & 31 & 694 & 17 & 20 & 15.9 & 2.0 & 14 & 5.8 & 36 & 10.3 & 65 \\
\hline SDR & 7.4 & 22 & 25 & 532 & 13 & 15 & 13.4 & 1.7 & 12.1 & 5.4 & 40 & 8.1 & 60 \\
\hline TAU Găgăuzia & 1.8 & 5.5 & 6.2 & 162 & 4,0 & 4,6 & 2.5 & 0.3 & 2.1 & 0.4 & 14 & 2.1 & 86 \\
\hline Total RM, ex. TAU LBD & 29.7 & 88 & 100 & 3550 & 88 & 100 & 116 & 15 & 100 & 72 & 62 & 44 & 38 \\
\hline TAU LBD & 4.2 & 12 & 100 & 475 & 12 & 100 & 670 & 85 & & 604 & 90 & 66 & 10 \\
\hline Dnestrovsk & 0.015 & 0.04 & $0.4^{3}$ & 11 & 0.3 & 2.3 & 555 & 71 & 83 & 553 & 100 & 1.9 & 0.3 \\
\hline Tiraspol & 0.05 & 0.15 & 1.2 & 135 & 3.4 & 28 & 22.1 & 2.8 & 3.3 & 1.3 & 5.9 & 20.8 & 94 \\
\hline Bender & 0.1 & 0.3 & 2.3 & 98,7 & 2.5 & 21 & 21.6 & 2.7 & 3.2 & 0.3 & 1.5 & 21.3 & 99 \\
\hline Râbnița & 0,025 & 0.07 & 0.6 & 48,5 & 1.2 & 10 & 14.1 & 1.8 & 2.1 & 8.4 & 59 & 5.9 & 41 \\
\hline Total RM & 33.8 & 100 & & 4,0 & 100 & & 786 & 100 & & 676 & 85 & 110 & 15 \\
\hline
\end{tabular}

Source: tables and figures of this paper are elaborated by the authors after data from Moldovan Water Agency (Direcția Bazinieră a Agenției „Apele Moldovei”, 2007-2016) 
Also, about 670 million $\mathrm{m}^{3}$ of water $(85 \%)$ were used by the consumers from TAU LBD, including 552 million $\mathrm{m}^{3}$ by the Thermoelectric Plant (TEP) from Dnestrovsk and about 22 million $\mathrm{m}^{3}$ in Tiraspol and Bender (Tighina) cities. Maximum water consumption in the TAU LBD is conditioned both by higher level of industrialization of the region promoted in the soviet period. The total volume of water used on the right bank of the Dniester River (without the municipality of Tighina) is on average only 116 million $\mathrm{m}^{3}$ per year or only $15 \%$ of the total volume of water used in Moldova. The volume of water used is conditioned by number and size of the urban centers as well as by the monitored irrigated areas from those districts.

In the North Region, was used, on average, 24.7 million $\mathrm{m}^{3}$, which represents only $3.1 \%$ of the total water used in Moldova and $21 \%$ of the water used on the right bank of the Dniester River (table 1). The maximum amount of water used is found in Balti city $\left(5 \mathrm{mil} . \mathrm{m}^{3}\right)$, and in the districts of Briceni $\left(2.5 \mathrm{mil} . \mathrm{m}^{3}\right)$, Soroca and Edinet $(2.4$ mil. $\mathrm{m}^{3}$ ) Floreşti $\left(2.0 \mathrm{mil} \mathrm{m}^{3}\right)$, which are a biggest surface and a higher development level of industry and irrigated agriculture (Direcția Bazinieră a Agenției „Apele Moldovei", 2007-2016). The minimum volume is recorded in the smaller districts, such as Donduseni (912 thousand $\left.\mathrm{m}^{3}\right)$ and Ocnita (1.3 million $\left.\mathrm{m}^{3}\right)$.

In the Central Region, was used, on average, 75.5 million $\mathrm{m}^{3}$ of water, which represents $10 \%$ of the total water used in RM and $65 \%$ of the water used on the right bank of the Dniester. The higher share of the Central Region is explained by the presence of Chisinau municipality, which consumes more than $40 \%$ (52 million $\mathrm{m}^{3}$ ) of the water used on the right bank of the Dniester River. In the central districts were used, on average, 24 million $\mathrm{m}^{3}$ of water or a quantity similar to that in the North Region (table 1). The maximum volume of water used is found in the districts of Anenii Noi $\left(3.8\right.$ million $\left.\mathrm{m}^{3}\right)$, Orhei $\left(3.3\right.$ million $\left.\mathrm{m}^{3}\right)$, Ungheni $\left(2.7\right.$ million $\left.\mathrm{m}^{3}\right)$, Criuleni and Dubasari $\left(2.0\right.$ million $\left.\mathrm{m}^{3}\right)$, which massively use for irrigation and domestic necessities, the surface waters captured from the Dniester and Prut riverbeds. The minimum volume of water is used in the districts of Nisporeni (856 thousand $\mathrm{m}^{3}$ ) and Şoldăneşti (894 thousand $\mathrm{m}^{3}$ ), with a smaller surface and more agrarian character.

The total volume of water used in the South Region is $\approx 16$ million $\mathrm{m}^{3}$ or only $2.0 \%$ of the total volume of water used in the Republic of Moldova and $14 \%$ of water used on the right bank of the Dniester river. The low share of this region is explained by its more pronounced agrarian character. In the SDR, was used, on average, 13.4 million $\mathrm{m}^{3}$ of water, and in the TAU Gagauzia -2.5 million $\mathrm{m}^{3}(0.3 \%)$. The maximum volume of water is used in the districts of Cahul (3.1 million $\left.\mathrm{m}^{3}\right)$ and Ştefan Vodă (2.8 million $\mathrm{m}^{3}$ ), which mainly use the surface waters captured from the Prut and Dniester riverbeds. The minimum volume was used in the smaller districts, including Basarabeasca $\left(764\right.$ thousand $\left.\mathrm{m}^{3}\right)$, Leova $\left(1.0\right.$ million $\mathrm{m}^{3}$ ) and Cimislia -1.1 million $\mathrm{m}^{3}$.

From surface sources were used, on average, 676 million $\mathrm{m}^{3}$ of water or $85 \%$ of total volume. In the TAU LBD from surface sources come $90 \%\left(604\right.$ million $\left.\mathrm{m}^{3}\right)$ of the L.S.G.D.C. 46 (2): 19-37 
waters used and in the right bank of the Dniester - over 60\% (Figure 2-3). Also, 90\% of the captured surface waters are used in the TAU LBD, including over $80 \%$ (553 million $\mathrm{m}^{3}$ ) only at TEP from Dnestrousk (Direcția Bazinieră a Agenției „Apele Moldovei", 2007-2016). Also, from surface sources are supplied majority of industrial companies from Rabnita and Dubasari towns, and big agriculture companies, especially for irrigation purposes.
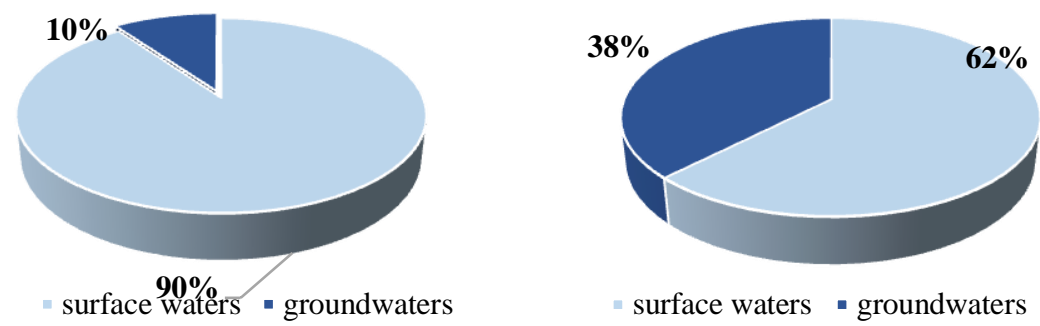

Figure 2-3. Share of surface and underground waters in the right and left bank of the Dniester river.

On the right bank of the Dniester river, the high share (62\%) of the surface sources is conditioned, almost exclusively, by the municipalities of Chisinau and Balti, which contribute $\approx 1 / 2$ in the total volume of water used. Also, in the Dniester river basin, surface sources predominate in the districts of Soroca (55\%), Anenii-Noi (54\%), Dubasari (62\%) and Ştefan Vodă $(64 \%)$. In the Prut river basin, the highest share of water from surface sources is recorded in the districts of Ungheni $(68 \%)$, Briceni (56\%), Edinet (51\%) and Cahul (48\%). In the other districts and in the Tiraspol and Bender cities is captured groundwater, and the riverbeds made only function of natural receivers of polluted wastewater (Bacal, 2010). Due to low flow and intensifying processes of climate aridity, the ability to explore surface water sources is very low. In addition, phreatic water has increased mineralization which significantly limits the development of irrigated agriculture.

From the underground sources, was used, on average, 110 million $\mathrm{m}^{3}$ of water, or only $15 \%$ of the total volume. At the same time, underground sources are predominating in the four of the six development regions (except TAU LBD and Chisinau) and in the most districts on both banks of the Dniester river. The maximum share $(\geq 70 \%)$ of water used from underground sources is attested in the districts of Hâncești and Cimișlia located in the Cogâlnic river basin, and in the TAU Găgăuzia located in the Ialpug river basin (Bejan et al., 2017).

\subsection{The dynamics of water use}

Despite the oscillating evolution conditioned by the rainwater regime and the economic situation, the total volume of water used in the Republic of Moldova shows, in the analysed period, a tendency to decrease, which is observed in the all regions (except TAU LBD) and in the absolute majority of administrative districts. 

Table 2. Dynamics of the total volume of water used in the regions of the Republic of Moldova, in million $\mathrm{m}^{3}$

\begin{tabular}{|c|c|c|c|c|c|c|c|c|c|c|c|c|}
\hline \multirow{2}{*}{ Regions and localities } & \multicolumn{10}{|c|}{ Years } & \multirow{2}{*}{ Average } & \multirow{2}{*}{ Growth } \\
\hline & 2007 & 2008 & 2009 & 2010 & 2011 & 2012 & 2013 & 2014 & 2015 & 2016 & & \\
\hline North & 27.7 & 24.8 & 27.3 & 23.8 & 24.4 & 25.2 & 24.3 & 23.3 & 23.6 & 23.0 & 24.7 & -17 \\
\hline incl. Bălți & 5.4 & 5.4 & 5.2 & 5.1 & 5.1 & 4.7 & 4.7 & 4.7 & 4.8 & 4.6 & 5.0 & -15 \\
\hline Central & 89.5 & 81.5 & 79.5 & 75.2 & 75.2 & 75.8 & 72.6 & 67.7 & 69.2 & 69.2 & 75.5 & -23 \\
\hline Central districts & 30.4 & 23.0 & 24.7 & 22.2 & 23.2 & 24.7 & 22.2 & 22.4 & 23.6 & 23.6 & 24.0 & -22 \\
\hline Chișinău munic. & 59.1 & 58.5 & 54.8 & 53.0 & 52.0 & 51.1 & 50.4 & 45.2 & 45.6 & 45.6 & 51.5 & -23 \\
\hline South & 22.4 & 17.8 & 19.1 & 15.7 & 14.8 & 14.4 & 14.6 & 12.9 & 14.0 & 13.5 & 15.9 & -40 \\
\hline SDR & 19.1 & 15 & 16.1 & 13.5 & 12.6 & 12.1 & 12.5 & 10.7 & 11.7 & 11.3 & 13.5 & -41 \\
\hline TAU Găgăuzia & 3.4 & 2.8 & 3.0 & 2.3 & 2.2 & 2.3 & 2.1 & 2.2 & 2.4 & 2.2 & 2.5 & -35 \\
\hline Total RM, ex. TAU LBD & 140 & 124 & 126 & 115 & 114 & 115 & 111 & 104 & 107 & 106 & 116 & -24 \\
\hline TAU LBD & 670 & 670 & 670 & 670 & 670 & 670 & 670 & 670 & 670 & 670 & 670 & 0 \\
\hline Dnestrovsk & 555 & 555 & 555 & 555 & 555 & 555 & 555 & 555 & 555 & 555 & 555 & 0 \\
\hline Tiraspol & 22.1 & 22.1 & 22.1 & 22.1 & 22.1 & 22.1 & 22.1 & 22.1 & 22.1 & 22.1 & 22.1 & 0 \\
\hline Bender & 21.6 & 21.6 & 21.6 & 21.6 & 21.6 & 21.6 & 21.6 & 21.6 & 21.6 & 21.6 & 21.6 & 0 \\
\hline Râbnița & 13.9 & 13.9 & 13.9 & 13.9 & 13.9 & 13.9 & 13.9 & 14.5 & 14.5 & 14.5 & 14.1 & +4 \\
\hline Total RM & 805 & 794 & 795 & 785 & 785 & 786 & 782 & 777 & 777 & 776 & 786 & -4 \\
\hline
\end{tabular}


Due to the high weight $(85 \%)$ of TAU LBD, where the volume of water used is almost constant, the total volume of water used in the RM is decreased by only $3-4 \%$ (table 2). At the same time, outside the TAU LBD, there is a reduction of $\approx 1 / 4$ of the total volume of water used, including in the Northern Region - with $17 \%$, in the Central Region - with $23 \%$ and in the South Region - with $40 \%$. The maximum reduction (2 times) is found in the districts, where predominate the surface sources used for irrigation, including the districts of Edinet, Anenii Noi, Dubasari, Hancesti, Causeni, Stefan Voda. Taraclia and Cantemir. The increase of water use $(<30 \%)$ is observed only in 7 districts, including in Donduseni, Soroca, Floresti, Teleneşti (located predominantly in the Raut river basin), Străşeni, Călăraşi and Cimişlia. At the same time, the official statistics of water consumption do not contain complete data, especially on consumption at hydropower, fishery, agriculture and households, which are not connected to centralized water supply networks, which significantly reduces the efficiency of water public management policies.

The volume of water used from surface sources, on the right bank of the Dniester River, shows a more pronounced negative trend, with about 35\% (figure 4), including in the North Region - 35\%, in the Central Region - 30\% (56\% in the central districts and only $22 \%$ in Chisinau), and in the South Region - more than 3 times. The maximum reduction (5 times) is found in the districts of Edinet, Drochia, Râşcani, Şoldăneşti, Rezina, Orhei, Hânceşti, Căuşeni and in the TAU Gagauzia. The increase of water use from surface sources is recorded only in 3 districts, including Donduseni (2.4 times), Soroca (+ 21\%) and Teleneşti (+ 56\%).

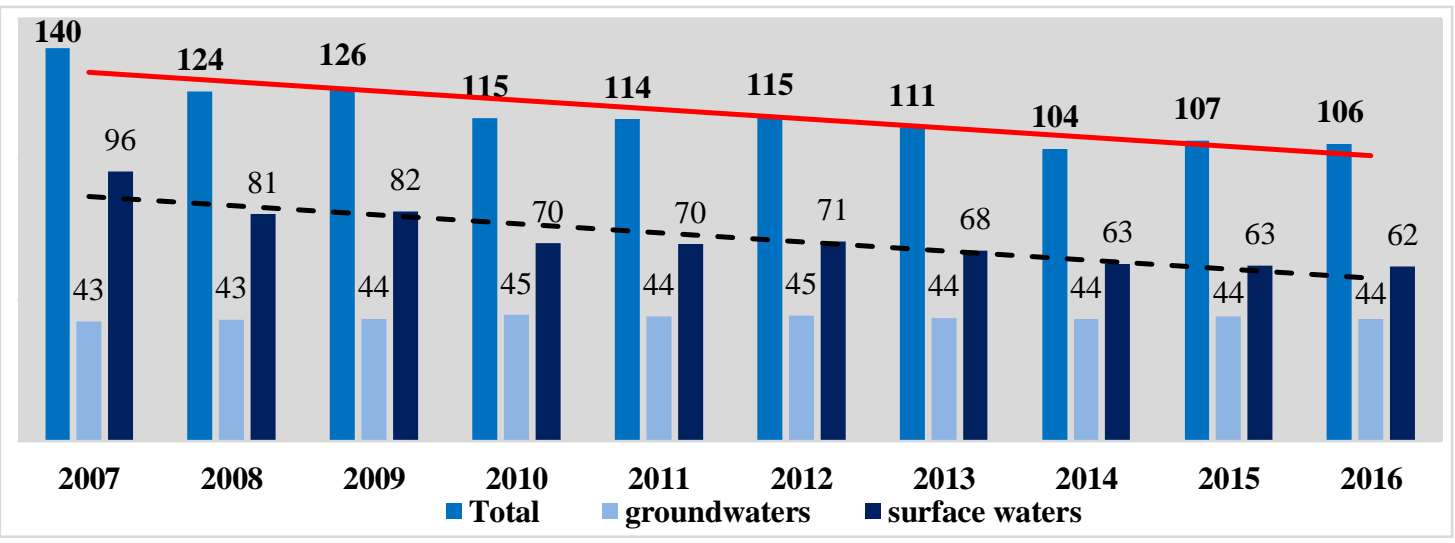

Figure 4. Dynamics of the total volume of water used on the right bank of Dniester, in million $\mathrm{m}^{3}$

At the same time, the volume of waters used from underground sources, on the right bank of the Dniester River, registers a slow growth $(+2 \%)$, including in the North Region $-3 \%$ and in the Central Region $-5 \%$, including in the central districts $-20 \%$. At the same time, in the South Region there is a decrease of about $5 \%$, and in the municipality of Chisinau - of 37\% (Direcția Bazinieră a Agenției „Apele Moldovei”, 
2007-2016). The positive dynamics of water consumption from underground sources is observed in the majority districts of the Republic. This situation is due to the recent extension of the centralized water supply network, especially for the household needs of the rural population and the majority of water is abstracted through artesian wells built and modernized with the financial support of the National Ecological Fund, German Technical Assistance Fund (GIZ) and other financing sources (Bejan et al., 2017). At the same time, a great part of newly built water supply networks are not completed with centralized sewerage networks and wastewater treatment plants, which significantly increases harmful impact on the environment and the human body. The maximum increase of groundwater consumption is found in the districts of Drochia (+56\%), Glodeni (+42\%), Orhei $(+61 \%)$, Ungheni $(+44 \%)$, Straseni $(+39 \%)$, Anenii Noi $(\%)$ and Stefan-Voda $(+37 \%)$. The decrease of the volume of water use from underground sources is observed in Balti (3 times) and Chisinau (-37\%) municipalities, as well as in the districts of Singerei (-15\%), Râşcani (-16\%), Dubasari $(-28 \%)$, Hânceşti $(-18 \%)$, Căuşeni $(-30 \%)$, Taraclia $(-23 \%)$, Basarabeasca $(-23 \%)$ and Cahul (-17\%).

\subsection{Branch structure of water use}

About $3 / 4\left(580\right.$ million $\left.\mathrm{m}^{3}\right)$ of the total volume of water are used by technological purposes, of which 568 million. $\mathrm{m}^{3}$ or $90 \%$ in the TAU LBD (fig. 5), including 549 million $\mathrm{m}^{3}$ only at TEP from Dnestrovsk. Also, energy companies with high water consumption are TEP-2 (925 th sm $\left.{ }^{3}\right)$ and TEP-1 (209 ths $\left.\mathrm{m}^{3}\right)$ from Chisinau, TEP from Balti $\left(20\right.$ ths $\left.\mathrm{m}^{3}\right)$, as well as hydroelectric power stations from Dubasari, but the volume of water used by them is not included in the Generalized Water Country Indicators Reports developed by the River Basin Directorate of the Moldovan Water Agency. A similar situation is witnessed in the Costesti-Stânca hydroelectric node, jointly exploited by Republic of Moldova and Romania. According of data from State Ecological Inspectorate ${ }^{2}$, the annual volume of water use at Costesti-Stanca hidrolelectric node is about 77 million $\mathrm{m}^{3}$ or a similarly volume of water used in the Chisinau municipality. The massive consumption of technological waters is attested in the industrial enterprises of the cities of Tiraspol (3.5 million $\left.\mathrm{m}^{3}\right)$, Râbnița (3.1 million $\mathrm{m}^{3}$ ) and Tighina $\left(1.7\right.$ million $\mathrm{m}^{3}$ ). For domestic purposes was used about $15 \%$ or 119 million $\mathrm{m}^{3}$, including 61 million $\mathrm{m}^{3}$ in the TAU LBD (table 3). Only $11 \%$ or 86 million $\mathrm{m}^{3}$ are used in agriculture, of which $\approx 47$ million $\mathrm{m}^{3}(6 \%)$ for irrigation, including 32.5 million $\mathrm{m}^{3}$ in the TAU LBD.

On the right bank of the Dniester River, about $50 \%$ (58 million $\left.\mathrm{m}^{3}\right)$ of the waters are used for domestic purposes (fig.6). In agriculture are used about 40\% (46

\footnotetext{
2 Rapoartele anuale privind calitatea factorilor de mediu şi activitatea Agenţiilor şi Inspecţiilor Ecologice (2007-2016)
} 
million $\mathrm{m}^{3}$ ) of the captured waters, including for irrigation $-12 \%\left(14\right.$ million $\left.\mathrm{m}^{3}\right)$. In addition, agriculture predominates absolutely in 4 of the 6 development regions of the Republic of Moldova, with the exception of Chisinau and TAU LBD (table 3). For technological purposes, are used only $10 \%$ of the captured waters, especially by the enterprises from the food industry, especially sugar factories from the northern region, vineries from the Central and Southern Regions, food company from Chisinau ${ }^{3}$, mining and construction materials industry from the Central and Northern Regions. Among the service companies we can mention medical institutions from Chisinau municipality and from Dubasari and Calarasi districts.
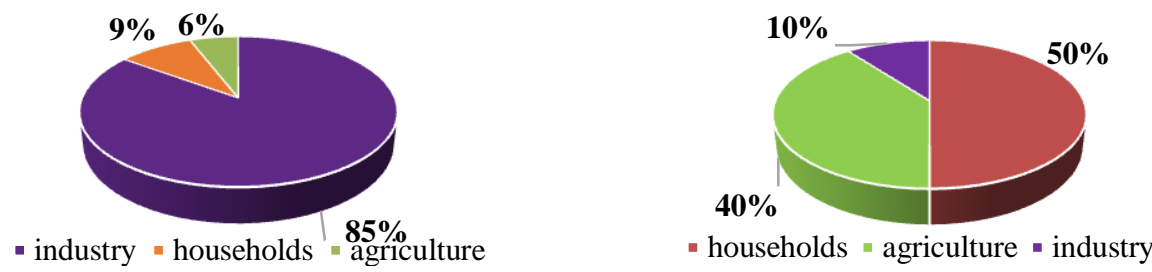

Figure 5-6. The main category of water use on the right and left banks of Dniester river of the RM

The water consumption of the households by regions is conditioned by the size and number of its urban centers. Due to the presence of Chisinau municipality, the Central Region is the largest consumer of domestic water in the Republic, with a volume of about 58 million $\mathrm{m}^{3}$ or more than $60 \%$ of the total volume of water used in this region. At the same time, in the central districts, the share of domestic waters is only $17 \%$, and over $3 / 4$ of the captured waters is used in agriculture, including $\approx 1 / 4-$ for irrigation (table 3).

Table 3. Water use, by the main usage categories, in the region of Republic of Moldova (average of 2007-2016 years)

\begin{tabular}{|c|c|c|c|c|c|c|c|c|c|c|c|}
\hline \multirow[t]{3}{*}{ Regions/cities } & \multirow{3}{*}{\begin{tabular}{|r} 
total \\
mil. $\mathrm{m}^{3}$
\end{tabular}} & \multicolumn{2}{|c|}{ household } & \multicolumn{2}{|c|}{ technological } & \multicolumn{6}{|c|}{ agriculture } \\
\hline & & \multirow[b]{2}{*}{ mil. $\mathrm{m}^{3}$} & \multirow[b]{2}{*}{$\%$} & \multirow[b]{2}{*}{ mil. $\mathrm{m}^{3}$} & \multirow[b]{2}{*}{$\%$} & \multicolumn{2}{|c|}{ total } & \multicolumn{2}{|c|}{ ex. irigation } & \multicolumn{2}{|c|}{ irigation } \\
\hline & & & & & & mil. $\mathrm{m}^{3}$ & $\%$ & mil. $\mathrm{m}^{3}$ & $\%$ & mil. $\mathrm{m}^{3}$ & $\%$ \\
\hline Northern region & 24.7 & 6.6 & 27 & 3.1 & 13 & 14.9 & 60 & 10.4 & 42 & 4.5 & 18 \\
\hline incl. Bălți & 5 & 3.4 & 69 & 1.5 & 30 & 0.15 & 3.0 & 0.15 & 3.0 & 0 & 0 \\
\hline Central Region & 75.5 & 47.8 & 63 & 8.1 & 11 & 18.9 & 25 & 13.2 & 17 & 5.7 & 7.5 \\
\hline Central districts & 24 & 4 & 17 & 1.1 & 5 & 18.3 & 76 & 12.9 & 54 & 5.4 & 23 \\
\hline Chișinău mun. & 51.6 & 43.8 & 85 & 7.0 & 14 & 0.6 & 1.2 & 0.34 & 0.7 & 0.26 & 0.5 \\
\hline Southern Region & 16.2 & 3.5 & 22 & 0.76 & 5 & 11.4 & 70 & 7.7 & 48 & 3.7 & 23 \\
\hline SDR & 13.7 & 2.7 & 19 & 0.65 & 5 & 10 & 73 & 6.5 & 48 & 3.4 & 25 \\
\hline TAU Găgăuzia & 2.5 & 0.9 & 34 & 0.1 & 4 & 1.4 & 56 & 1.2 & 48 & 0.4 & 16 \\
\hline Total RM, ex. TAU LBD & 116 & 58 & 50 & 12 & 10 & 46 & 40 & 31.3 & 27 & 13.9 & 12 \\
\hline TAU LBD & 670 & 61 & 9 & 568 & 85 & 39.3 & 5.9 & 6.8 & 1.0 & 32.5 & 4.9 \\
\hline Dnestrovsk & 555 & 2.7 & 0.5 & 549 & 99 & 0 & 0 & 0 & 0 & 0 & 0 \\
\hline Tiraspol & 22 & 18.6 & 84 & 3.5 & 16 & 0 & 0 & 0 & 0 & 0 & 0 \\
\hline Bender & 22 & 19.9 & 92 & 1.7 & 8 & 0.01 & 0 & 0.01 & 0 & 0 & 0 \\
\hline
\end{tabular}

\footnotetext{
3 Rapoartele anuale privind calitatea factorilor de mediu şi activitatea Agenţiilor şi Inspecţiilor Ecologice (2007-2016)
} 


\begin{tabular}{lccccccccccc} 
Rîbnița & 14 & 11.2 & 79 & 3.1 & 22 & 0 & 0 & 0 & 0 & 0 & 0 \\
\hline Total RM & $\mathbf{7 8 6}$ & $\mathbf{1 1 9}$ & $\mathbf{1 5}$ & $\mathbf{5 8 0}$ & $\mathbf{7 4}$ & $\mathbf{8 5 . 1}$ & $\mathbf{1 1}$ & $\mathbf{3 8 . 4}$ & $\mathbf{4 . 9}$ & $\mathbf{4 6 . 7}$ & $\mathbf{5 . 9}$ \\
\hline
\end{tabular}

Major consumption for domestic purposes is attested in the districts of Ungheni (1.2 million $\mathrm{m}^{3}$ ) and Orhei (800 thousand $\mathrm{m}^{3}$ ), which have the largest urban centers of the Central Development Region. In the Northern Region, for domestic purposes are used, on average, 6.6 million. $\mathrm{m}^{3}$ (27\%) of water, including in the Balti city -3.5 million $\mathrm{m}^{3}$, in the Soroca district - 630 thousand $\mathrm{m}^{3}$ and in the Edinet district - 400 thousand $\mathrm{m}^{3}$. In the South Region, were used, on average, only 3,5 million $\mathrm{m}^{3}$ $(22 \%)$ of domestic water, including in the Cahul district -1.1 million $\mathrm{m}^{3}$ and in the TAU Gagauzia - 856 thousand $\mathrm{m}^{3}$. However, a large part of water for domestic needs supplied to population is widely used in the household for irrigation and breading farm animals etc. Over $90 \%$ of the total volume of water used for domestic needs is captured by municipal enterprises. On second position, there are agro-food enterprises, among which are the sugar factories from the North Region and the food enterprises from Chisinau (Bacal, 2010). Among the service enterprises we mention the medical institutions from Chisinau and from the districts of Dubasari and Calarasi.

In the right bank of Dniester river, share of agriculture exceed $40 \%$ (46 million $\left.\mathrm{m}^{3}\right)$ of the water used. The maximum share $(\geq 70 \%)$ of agriculture is attested in the South Region, with a lower level of industrialization and urbanization. In addition, this region faces a permanent shortage of rainfall. Water use in agriculture varies on function by the size of the region's districts, by water resources and by the technical and economic capabilities of water capturing from available sources, especially from the Dniester and Prut riverbeds. Therefore, the maximum water consumption in agriculture is observed in the districts of Ştefan Vodă (2.6 million m³), Căuşeni (2.0 million $\mathrm{m}^{3}$ ) and Cahul (1.6 million $\left.\mathrm{m}^{3}\right)$.

In the Northern Region for agriculture there are used about 60\% ( $\approx 15$ million m3) of the captured waters, which is due to the presence of Balti municipality, but also to a higher level of industrialization and water supply. Maximum water use for agricultural purposes is found in the districts of Briceni $\left(2,4\right.$ million $\left.\mathrm{m}^{3}\right)$, Soroca, Edinet and Riscani $\left(1,6\right.$ million $\left.\mathrm{m}^{3}\right)$, in which the water is capture through the Prut and Dniester riverbeds. In addition, in these districts have been preserved or restored the agricultural and irrigation big enterprises. In the Central Region for agricultural purposes are used only $1 / 4$ of the captured waters. The minimum share is due exclusively to Chisinau municipality, in which it is consumed more than $2 / 3$ of the total volume of water used in this region. Moreover, in the Chisinau for agriculture are used only about $1 \%$ of water captured, and the rest used for domestic (85\%) and industrial purposes (14\%). At the same time, in the central districts, over $3 / 4$ of the captured waters are used for agriculture, which is explained by both the agrarian character and the higher providing with water resources (compared to the southern 
region). The maximum water consumption in agriculture is found in the districts with direct access to the Dniester riverbed and located in the proximity of Chisinau (the main market), including Anenii Noi $\left(3.0\right.$ million $\left.\mathrm{m}^{3}\right)$, Orhei $\left(2.2\right.$ million $\left.\mathrm{m}^{3}\right)$, Criuleni $\left(1.9\right.$ million $\left.\mathrm{m}^{3}\right)$ and Dubasari $\left(1.7\right.$ million $\left.\mathrm{m}^{3}\right)$. The minimum share for the districts of Ungheni (44\%) and Cahul (53\%) is due to higher dimensions and industrial specialization of these district centres.

For irrigation are used, on average, 42 million $\mathrm{m}^{3}$ (5.5\%), including 32.5 million $\mathrm{m}^{3}$ on the left bank of Dniester river, which have a much extended and more developed irrigation infrastructure. On the right side of the Dniester River for irrigation are used, on average, $\approx 14$ million $\mathrm{m}^{3}(12 \%)$. In the Northern Region, for irrigation was use, on average, 4.5 million $\mathrm{m}^{3}(18 \%)$ and in the Central Region -5.7 million $\mathrm{m}^{3}(7.5 \%)$. In the Central and Southern Development Regions for irrigation are used $\approx 1 / 4$ of the abstracted water. The volume of water used for irrigation, is conditioned by the surface of basins and administrative territorial units in the perimeter of the hydrographical area, by the water sources used for these purposes and by the presence of big agricultural farms in the region. Therefore, the maximum volume of water used for irrigation is found in Ştefan-Vodă districts (1.8 million m3), Anenii Noi $\left(1.5\right.$ million $\left.\mathrm{m}^{3}\right)$, Briceni $\left(1.4\right.$ million $\left.\mathrm{m}^{3}\right)$ and Dubăsari $\left(1.2\right.$ million $\left.\mathrm{m}^{3}\right)$, where so far there are large irrigation stations.

On the right bank of Dniester river, for technological purposes are used about 12 million $\mathrm{m}^{3}$ of water or $10 \%$ of total volume of water use, including 3,1 million $\mathrm{m}^{3}$ $(13 \%)$, in the North Region, 1,1 million $\mathrm{m}^{3}(5 \%)$ in the central districts, 7 million $\mathrm{m}^{3}$ $(14 \%)$ in the Chisinau municipality and 760 thousand $\mathrm{m}^{3}(5 \%)$ - in the South Region. However, according to the data of State Ecological Inspectorate, in the 2016 year, the at the Hydro-energetic Node Costesti-Stanca was used 77 million $\mathrm{m}^{3}$ of water or by or 6 times more than the total consumption of technological waters on the right side of the Dniester.

In the Northern Region, the biggest consumers of technological waters are agro-food complex, energetics, mining and construction materials companies, water supply companies, service and transport enterprises. The biggest and most relevant consumers of technological water from agro-food complex are: sugar factories from Cupcini, Edinet district (327 thousand (ths.) $\mathrm{m}^{3}$ ), from Glodeni $\left(293\right.$ ths. $\left.\mathrm{m}^{3}\right)$, Falesti (228 ths $\left.\mathrm{m}^{3}\right)$, Donduseni (138 ths. $\left.\mathrm{m}^{3}\right)$ and Drochia towns $\left(120\right.$ ths. $\left.\mathrm{m}^{3}\right)$, from Ghindesti, Floresti district (108 ths. $\mathrm{m}^{3}$ ); dairies SA Incomlac from the towns of Bălţi (123 ths. $\left.\mathrm{m}^{3}\right)$ and Râşcani $\left(13,3\right.$ ths. $\left.\mathrm{m}^{3}\right)$, Inlac from Edinet (27.2 ths. $\left.\mathrm{m}^{3}\right)$, butter factory from Floreşti; cereal processing centers from Mărculeşti, Floreşti (144 ths. $\left.\mathrm{m}^{3}\right)$, Balti (29 ths. $\mathrm{m}^{3}$ ), Otaci, Râşcani and Singera; oil production plants SA "Floarea Soarelui" from

4 Rapoartele anuale privind calitatea factorilor de mediu şi activitatea Agenţiilor şi Inspecţiilor Ecologice (2007-2016) 
Bălți (129 ths. $\mathrm{m}^{3}$ ) and SA Flor from Floresti; canning factories, including SA Natur Bravo from Edinet (176 ths. $\left.\mathrm{m}^{3}\right)$ and Floresti $\left(18\right.$ ths. $\left.\mathrm{m}^{3}\right)$, SA Alfa-Nistru from Soroca (15.8 ths. $\mathrm{m}^{3}$ ); poultry farms near Bălti city, including from districts of Râşcani and Falesti; meat companies, including SA Basarabia Nord from Balti $\left(67\right.$ ths. $\left.\mathrm{m}^{3}\right)$, from Soroca and Singerei districts; companies of extraction and bottling of mineral water from districts of Floresti $\left(144\right.$ ths. $\left.\mathrm{m}^{3}\right)$, Singerei $\left(40\right.$ ths. $\left.\mathrm{m}^{3}\right)$ and Soroca; large agricultural enterprises from the Drochia, Râşcani and Glodeni districts; bakery factories from the urban centers and large villages. Also, we can mention the Factory for production of gypsum products (Knauf) from Bălţi (13.7 ths. $\left.\mathrm{m}^{3}\right)$, the mining enterprises from the Soroca, Floreşti, Briceni and Râşcani districts. Massive consumption of water for production is attested at the Costeşti-Stânca Hydro-Power Node $\left(77\right.$ million $\left.\mathrm{m}^{3}\right)$ and at thermo-electric plant CET Nord from Balti $\left(204\right.$ ths. $\left.\mathrm{m}^{3}\right)$. In the communal sector is mentioned the municipal enterprises from Balti $\left(783\right.$ ths. $\left.\mathrm{m}^{3}\right)$, Edinet $\left(147\right.$ ths. $\left.\mathrm{m}^{3}\right)$, Sangerei (189 ths. $\mathrm{m}^{3}$ ) and Donduseni $\left(81\right.$ ths. $\left.\mathrm{m}^{3}\right)$. An average consumption of water for production is attested at the hospitals from Balti city and district centers, and also at the railway companies from Balti and Ocnita ${ }^{5}$.

In the Central Development Region, the bigest and most widespread water consumers for production are: wine factories from Ialoveni district (68.6 ths. $\left.\mathrm{m}^{3}\right)$, including Bardar Winery (18.3 ths. $\left.\mathrm{m}^{3}\right)$, Cascad Vin from Ialoveni town (13.8 ths. $\left.\mathrm{m}^{3}\right)$, Asconi from Puhoi (13.2 ths. $\mathrm{m}^{3}$ ) and the famous winery from Milestii Mici (9 ths. $\left.\mathrm{m}^{3}\right)$, Străşeni district $\left(34\right.$ ths. $\left.\mathrm{m}^{3}\right)$, including the Romaneşti SA (25 ths. $\left.\mathrm{m}^{3}\right)$, Orhei district $\left(31\right.$ ths. $\left.\mathrm{m}^{3}\right)$, including Chateau Vartely from Orhei $\left(9.2\right.$ ths. $\left.\mathrm{m}^{3}\right)$, Aneni Noi district $\left(31\right.$ ths. $\left.\mathrm{m}^{3}\right)$, including SA Agrovin Bulboaca $\left(23\right.$ ths. $\left.\mathrm{m}^{3}\right)$ and from Calarasi district $\left(16.5\right.$ ths. $\left.\mathrm{m}^{3}\right)$, including Calarasi Divin SA $\left(14\right.$ ths. $\left.\mathrm{m}^{3}\right)$; the poultry factories from the proximity of Bălţi city, including from Băneştii Vechi (14 ths. $\mathrm{m}^{3}$ ) and Sarateni Vechi, Teleneşti district, as well as in the proximity of Chisinau city, including from Floreni $\left(60\right.$ ths. $\left.\mathrm{m}^{3}\right)$, Hîrbovăț $\left(25\right.$ ths. $\left.\mathrm{m}^{3}\right)$ and Bulboaca, from Bucovăţ, Străşeni district (17.6 ths. $\left.\mathrm{m}^{3}\right)$, and Văduleni from Criuleni district (10.4 ths. $\left.\mathrm{m}^{3}\right)$; pig farms, including Pukoven SRL from Roşcani(156 ths. $\left.\mathrm{m}^{3}\right)$ and Funny Pig from Chirca (24.3 ths. $\mathrm{m}^{3}$ ), both from Anenii Noi district, SRL Porco Bello from Cimişeni, Criuleni district (49 ths. $\mathrm{m}^{3}$ ), Moldsuinhibrid (16.1 ths. $\mathrm{m}^{3}$ ) from Pohorniceni, Orhei district; meat processing centers from the districts of Ialoveni $\left(26\right.$ ths. $\left.\mathrm{m}^{3}\right)$ and Criuleni; canning factories from Cosnita, Dubasari $\left(73\right.$ ths. $\left.\mathrm{m}^{3}\right)$, Anenii Noi $\left(30\right.$ ths. $\left.\mathrm{m}^{3}\right)$ and Calarasi (5.7 ths. $\mathrm{m}^{3}$ ); large agricultural companies from Criuleni, Anenii Noi and Dubasari districts; cement factory SA Lafarge from Rezina (130 ths. $\left.\mathrm{m}^{3}\right)$, quarries from Cobuşca, Anenii Noi district (26 ths. $\left.\mathrm{m}^{3}\right)$ and from Micăuţi, Străşeni district (4.0 ths. $\left.\mathrm{m}^{3}\right)$.

5 Rapoartele anuale privind calitatea factorilor de mediu şi activitatea Agenţiilor şi Inspecţiilor Ecologice (2007-2016) 
In the Chisinau municipality, the biggest consumers of technological waters are: the water supply companies, including SA Apă Canal $\left(7.0\right.$ million $\left.\mathrm{m}^{3}\right)$; food industry, including beer factory SA Vitanta Intravest $\left(465\right.$ ths. $\left.\mathrm{m}^{3}\right)$, the famous candy factory SA Bucuria (191 ths. $\left.\mathrm{m}^{3}\right)$, Bread Factory SA Franzeluta (96.4 ths. $\left.\mathrm{m}^{3}\right)$, sausage factory SA Carmez SA (75 thhs. $\left.\mathrm{m}^{3}\right)$, the Yeast Factory $\left(58.5\right.$ ths. $\left.\mathrm{m}^{3}\right)$, the Tobacco Factory (57.8 ths. $\left.\mathrm{m}^{3}\right)$, the dairy factory SA JLK $\left(24.4\right.$ ths. $\left.\mathrm{m}^{3}\right)$ and the winery from Cricova (27.3 ths. $\mathrm{m}^{3}$ ); thermoenergetic complex, including thermoelectric power plants CET-2 (787 ths. $\left.\mathrm{m}^{3}\right)$ and CET-1 (340 ths. $\left.\mathrm{m}^{3}\right)$, as well as the company for production and distribution of thermal energy SA Termocom (115 ths. $\left.\mathrm{m}^{3}\right)$; production of building materials, including glass factories (114 ths. $\left.\mathrm{m}^{3}\right)$, SA Macon $\left(15.7 \mathrm{~m}^{3}\right)$; light industry, including factory for production of artificial leather SA Piele (46.3 ths. $\left.\mathrm{m}^{3}\right)$, Carpet Factory SA Floare Carpet (18.4 ths. $\left.\mathrm{m}^{3}\right)$, clothing factory SA Ionel (8.6 ths. $\left.\mathrm{m}^{3}\right)$; production of furniture and paper, including the Factory for Cardboard Manufacturing (42.8 ths. $\left.\mathrm{m}^{3}\right)$; the chemical industry, including cosmetics factory SA Viorica Cosmetic ( 6.7 ths. $\left.\mathrm{m}^{3}\right)$; railway enterprises and hospitals.

As a result of industrial underdevelopment and the lack of rainfall, the water use in the South Region is much lower compared to the other regions of the Republic. The biggest consumers of water for production in the South Region are: wine factories from TAU Gagauzia $\left(66.3\right.$ ths. $\left.\mathrm{m}^{3}\right)$, Causeni district $\left(14.8\right.$ ths. $\left.\mathrm{m}^{3}\right)$, including from Salcuta village (10.4 ths. $\left.\mathrm{m}^{3}\right)$, Ştefan Vodă district $\left(26\right.$ ths. $\left.\mathrm{m}^{3}\right)$, including wineries form Carahasani $\left(27.7 \mathrm{~m}^{3}\right)$ and Purcari $\left(12.4\right.$ ths. $\left.\mathrm{m}^{3}\right)$, from districts of Cahul (43 ths. $\left.\mathrm{m}^{3}\right)$, Cantemir (11.3 ths. $\mathrm{m}^{3}$ ) and Taraclia (19.2 ths. $\left.\mathrm{m}^{3}\right)$, including from Tvardita (8.4 ths. $\left.\mathrm{m}^{3}\right)$; canning factories, including from Olăneşti, Ştefan Vodă district (25 ths. $\left.\mathrm{m}^{3}\right)$ and from Căuşeni town $\left(23\right.$ ths. $\left.\mathrm{m}^{3}\right)$; the elevators from Causeni $\left(13.7\right.$ ths. $\left.\mathrm{m}^{3}\right)$ and Iargara, Leova district $\left(16,8\right.$ ths. $\left.\mathrm{m}^{3}\right)$; bakery factories from Cahul $\left(13\right.$ ths. $\left.\mathrm{m}^{3}\right)$ and from other district centers; the big agricultural companies; water supply companies from Comrat (528 ths. $\left.\mathrm{m}^{3}\right)$, and Cahul (270 ths. $\left.\mathrm{m}^{3}\right)$,

As a result of the absolute predominance of industrial enterprises from the left bank of the Dniester River, especially of TEP from Dnestrovsk, the total volume of water used in the RM for technological purposes registered an insignificant decrease. At the same time, on the right bank of the Dniester river, there is more pronounced negative dynamics (-21\%) of water used for these purposes (figure 7 ).

The negative dynamics is observed in the all regions, including with $38 \%$ - in the North Region, with $31 \%$ - in the central districts and with $15 \%$ - in the South Region. Also, the negative trend is found in the Balti $(-41 \%)$ and Chisinau (-11\%) cities and in the absolute majority of administrative districts. The negative dynamics is conditioned by decline of the volume of industrial productions based on massive water consumption, as well as the transition to technologies with lower water use. Maximal reduction is observed in the in the districts of Hancești and Taraclia (4 times), Glodeni, Rascani, Edineț, Basarabeasca (3 times), Teleneşti and Rezina (2 
times). At the same time, the increase of water use for technological purposes is registered in the districts of Drochia (2,7 times), Briceni and Cantemir (2 times), Aneni Noi (+56\%), Nisporeni (+50\%), Căușeni (+33\%), Fălești (+27\%) and Călarași $(+25 \%)$.

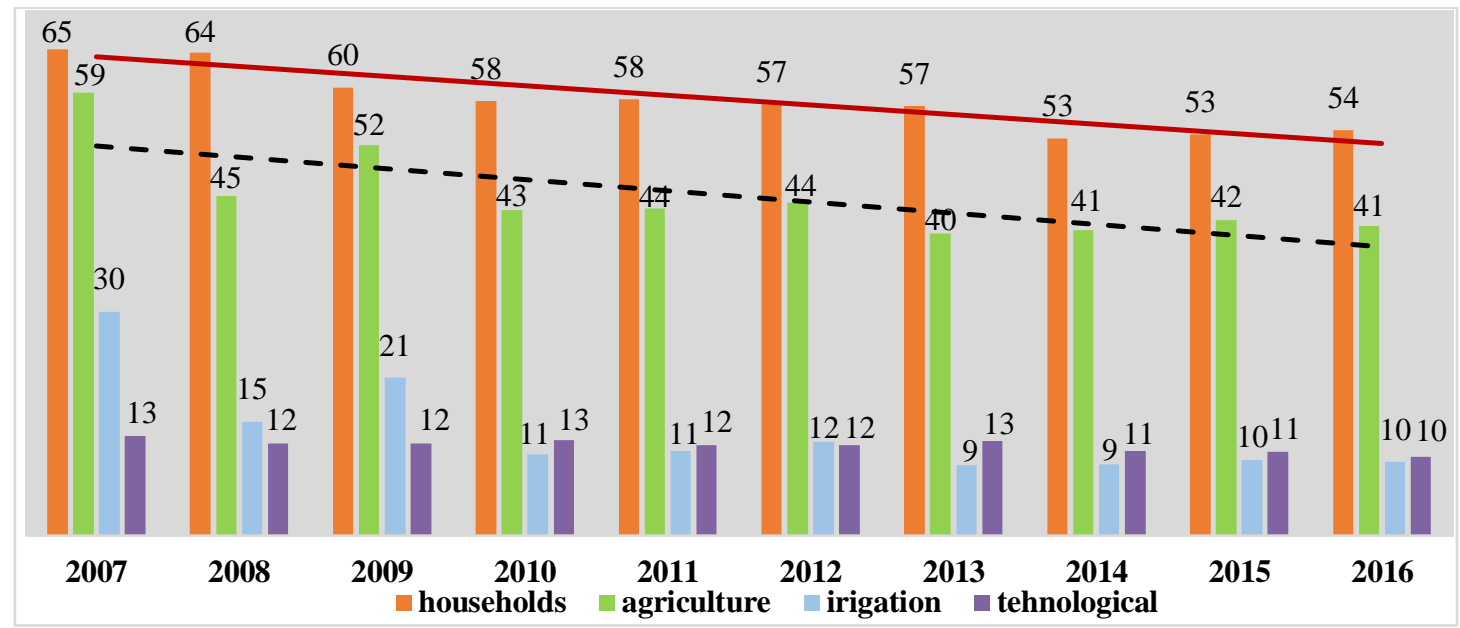

Figure 7. The dynamics of the water use on the right bank of Dniester River, in million $\mathrm{m}^{3}$

The volume of water used for domestic purposes recorded also the negative dynamics of about $10 \%$ or from 125 million $\mathrm{m}^{3}$ to $\approx 115$ million $\mathrm{m}^{3}$. In the analyses period (2007-2016), the total volume of water used for households in the TAU LBD is almost constant. However, on the right bank of the Dniester river, there is slow negative dynamics $(-17 \%)$ of water used for these purposes or from 65 million $\mathrm{m}^{3}$ to 54 million $\mathrm{m}^{3}$ (figure 7). This negative trend is conditioned, almost exclusively, by reduction, with $1 / 4$, of water use for domestic purpose in the Chisinau municipality. At the same time, in the other development regions from the right bank of Dniester river is observed a positive dynamics of water use for domestic purposes, including with $13 \%$ - in the North Region and in the central districts and with $16 \%$ - in the South Region. The positive dynamics is due to the recently rapid expansion of water supply networks exclusively based on the underground water sources. The increase of volume of water use for domestic purposes is found in the majority (22) of administrative districts, as well as in the Balti city and in the TAU Găgăuzia (+20\%). The maximum increase is observed in the districts of Strășeni (4,2 times), Soroca, Râscani, Cimișlia and Basarabeasca (2 times), Telenești (+71\%) and Șoldănești (+60\%). However, the maximum decrease of water use in the domestic purposes is registered in the districts of Dubăsari (2 times), Glodeni, Aneni Noi, Basarabeasca (-40\%) and Ocnița (-25\%).

The volume of water used in agriculture also decreased, on average, with $18 \%$, from $\approx 99$ mil. $\mathrm{m}^{3}$ to $80,5 \mathrm{mil} . \mathrm{m}^{3}$. The negative trend is due exclusively to 
situation on the right bank of the Dniester river, where volume of water used in agriculture decrease with $30 \%$, from $59 \mathrm{mil} . \mathrm{m}^{3}$ to $41.2 \mathrm{mil} . \mathrm{m}^{3}$ (figure 7 ). The negative dynamics is observed in the all regions and is intensifying from the north to the south of the Republic. Thus, in the North Region the volume of water use in agriculture are decrease with $22 \%$, in the central districts - with $24 \%$ and by 2 times in the South Region. This regularity is due to the similar tendency of worsening of the natural (climate) and economic conditions from the north to the south of the Republic, being more pronounced in the waters used in irrigation. The negative trend is found in the absolute majority of administrative districts (25 of 32), as well as in the Balti and Chisinau (-25\%) municipalities and TAU Gagauzia (-38\%). The maximum decrease of water used for agriculture is registered in the districts of Causeni ( $\approx 3$ times), Stefan Voda, Cantemir and Taracalia (2 times) from Southern Region, Rascani from Northern Region, Dubasari and Hancesti from Central Region (2 times). The increase of water use in agriculture is observed in the 4 districts of North Region (Donduseni, Falesti, Soroca, Glodeni) and in the Telenesti district from Central Region, but in the all districts from South Region is not attested an increase.

On the right bank of Dniester river, the total volume of water used in irrigation has decreased by about 3 times, from 29.8 million $\mathrm{m}^{3}$ to 9.7 million $\mathrm{m}^{3}$ (figure 7), including in the South Region - by 6 times, in the Central districts - by 2.6 times, and in the North Region - by 2.6 times has determined the decrease of the total volume of used water, especially from surface sources. This situation is conditioned both by worsening economic situation in agriculture and intensifying of aridity processes as well as by the spread of the phenomenon of incomplete recording of water usage for these purposes. The highest decreasing rates (over 5 times) of the volume of water used for irrigation is attested in the all southern districts, such as in the districts of Hancesti, Rezina, Soldanesti and Orhei from Central Region, Drochia, Edinet, Rascani and Glodeni from North Region. The increase of water use for is observed only in the 2 of 32 districts, including ihe districts of Donduseni (2.4 times) from North Region and in the Telenesti (+56\%) from Central Region.

\section{Conclusions}

From surface sources comes $85 \%$ of water use. However, the absolute majority of localities from Republic of Moldova are supplied from underground sources.

The total volume of water use is conditioned by the number and size of urban centres, as well as by the level of recording and monitoring of the water use for domestic and agricultural purposes. Due to the presence of TEP from Dnestrosk and to higher level of industrialization, in the TAU LBD is consumed more than $80 \%$ of the total volume of water used in the Republic of Moldova. On the second position is situated Chisinau (6.6\%) municipality, followed by the North and Central regions 
(3\% each). As a result of industrial underdevelopment and the lack of rainfall, the water use in the South Region is much lower compared to the other regions of the Republic.

In the period under review, the volume of water registers a significant decrease which is conditioned, mainly, by similar decreasing of water abstracted from surface sources and used for different agricultural activities, especially for irrigation. The negative dynamics of water use is observed in the all regions (except TAU LBD) and in the absolute majority of administrative districts.

Overall, about $3 / 4$ of the total volume of water are used for technological purposes, $15 \%$ for domestic needs and only $11 \%$ for agriculture. At the same time, on the right bank of the Dniester River, about $50 \%$ of the waters are used for domestic purposes, $40 \%$ - for agriculture and only $10 \%$ for technological purposes. The maximum volume of water is used by industrial enterprises from left bank of Dniester river and Chisinau city, by householders from Chisinau and over urban centers. In the rural areas, absolute majority of water is used for agricultural activities.

Despite recent significant expansion of water supply network, the most of rural population continues to use polluted water from wells.

\section{References}

BACAL P., 2010. Gestiunea protecției mediului înconjurător în Republica Moldova. Aspecte teoretice și aplicative. Chişinău: ASEM, 2010, 240 p.

BACAl P., BurdujA D.. 2017. Dynamics and branch structure of water consumption in the Republic of Moldova. In: Present Environment and Sustainable Development, Volume 11, no. 2, 2017 pp. 187-201.

Bejan Iu., Nedealcov N., BOBOC N., Bacal P. ET All. (2017). Planul de Gestionare a Districtului Bazinului Hidrografic Dunărea-Prut și Marea Neagră. Ciclul I, 2017-2022. Chișinău. 150 p. ISBN 978-9975-96121-4-1

CAZAC V., MihăIlescu C., BejenARU GH., 2010. Resursele acvatice ale Republicii Moldova. Apele de Suprafață. Chișinău, Ed. Știința. 248 p

Directia BAZINIERA A AgENTIEI,,APELE MOldoveI”. (2007-2016).Rapoartele anuale generalizate privind Indicii de gospodărire a apelor în Republica Moldova.

*** Legea nr. 438 din 28.12.2006 privind dezvoltarea regională în Republica Moldova. În: Monitorul Oficial nr. 021 din 16.02.2007. 
